\title{
Oral administration of n-3 fatty acids positively affect the mucosal lesions after experimental ischemic enteritis in the rat
}

\author{
La administración oral de ácidos grasos n-3 afecta positivamente las lesiones de la \\ mucosa después de la enteritis isquémica experimental en la rata
}

Zambia Koukouritaki, loannis Mantzoros, Orestis loannidis*, Styliani Parpoudi, Konstantinos Galanos-Demiris, Panagiotis Christidis, Manousos G. Pramateftakis, Efstathios Kotidis, Nikolaos Ouzounidis, Charalambos Dimitriadis, and Stamatios Angelopoulos

Department of Surgery, School of Medicine, Aristotle University of Thessaloniki, Thessaloniki, Greece

\begin{abstract}
Aim: The purpose of the study was to evaluate the effect of oral administration of $n-3$ polyunsaturated fatty acids in experimental ischemic enteritis in rats. Methods: Forty Wistar rats were submitted to control narrowing of the superior mesenteric artery and were divided in two groups: N3 polyunsaturated fatty acids, which received a high-molecular polymer solution of artificial total enteral nutrition enriched with n-3 fatty acids and CONTROL which received a high-molecular polymer solution of artificial total enteral nutrition. Results: Reduction of the animals' body weight was observed in both groups, but there was no difference between the two groups. Regarding the level of cytokines interleukin (IL)-1b, IL-6, and tumor necrosis factor a (TNF-a) there was no statistically significant difference between the two groups. Ischemic lesions to the small bowel mucosa were observed in both groups. A statistically significant difference in the extent of intestinal lesions was observed between the two groups with the animals that received enteral nutrition enriched with n-3 fatty acid developing fewer lesions. Conclusion: Enteral nutrition enriched with $n-3$ polyunsaturated fatty acids reduces the mucosal lesions caused by mesenteric ischemia compared to standard enteral nutrition, by modifying the local, but not the systemic, immune, and inflammatory response.
\end{abstract}

Key words: Cytokines. Immunonutrition. Intestinal ischemia. N-3 fatty acids. Small bowel. Ischemic enteritis.

\section{Resumen}

Objetivo: El propósito del estudio fue evaluar el efecto de la administración oral de ácidos grasos poliinsaturados n-3 en enteritis isquémica experimental en ratas. Métodos: 40 ratas Wistar fueron sometidas a un estrechamiento controlado de la arteria mesentérica superior y se dividieron en dos grupos: N3PUFA, que recibieron una solución de polímero de alto peso molecular de nutrición enteral total artificial enriquecida con ácidos grasos n-3 y CONTROL que recibió un alto -Solución de polímero molecular de nutrición enteral total artificial. Resultados: Se observó una reducción del peso corporal de los animales en ambos grupos, pero no hubo diferencias entre los dos grupos. Con respecto al nivel de citocinas IL-1b, IL-6 y TNF-a, no hubo diferencia estadísticamente significativa entre los dos grupos. Se observaron lesiones isquémicas de la mucosa del intestino delgado en ambos grupos. Se observó una diferencia estadísticamente significativa en la extensión de las lesiones intestinales entre los dos grupos y los animales que recibieron nutrición enteral enriquecida con ácido graso n-3 desarrollaron

\footnotetext{
Correspondence:

*Orestis loannidis

Alexandrou Mihailidi 13 Date of reception: 20-09-2020

C.P. 54640 Thessaloniki, Greece Date of acceptance: 16-12-2020

E-mail: iorestis@auth.gr

DOI: $10.24875 /$ CIRU.20001023

Cir Cir. 2021;89(6):776-784

Contents available at PubMed

www.cirugiaycirujanos.com

0009-7411/@ 2020 Academia Mexicana de Cirugía. Published by Permanyer. This is an open access article under the terms of the CC BY-NC-ND license (http://creativecommons.org/licenses/by-nc-nd/4.0/).
} 
menos lesiones. Conclusión: La nutrición enteral enriquecida con ácidos grasos poliinsaturados n-3 reduce las lesiones mucosas causadas por isquemia mesentérica en comparación con la nutrición enteral estándar, al modificar la respuesta local, pero no sistémica, inmunitaria e inflamatoria.

Palabras clave: Citocinas. Inmunonutrición. Isquemia intestinal. Ácidos grasos n-3. Intestino delgado. Enteritis isquémica.

\section{Introduction}

Ischemic enteritis is a vascular disease which presents with a very poor prognosis'. The causes of acute mesenteric ischemia include acute occlusion of the arterial or venous system. Particularly, acute arterial embolization (50\%), acute arterial thrombosis (25\%), and thrombosis of the mesenteric vein (5\%). The nonocclusive intestinal ischemia (non-occlusive mesenteric ischemia) is the result of a decrease in blood supply to the superior mesenteric artery due to visceral vasospasm ${ }^{2-4}$. The clinical consequences of the disease include ischemic bowel necrosis, sepsis, and death and are related to the time of diagnosis. Therefore, early diagnosis and therapeutic intervention are considered mandatory ${ }^{5}$. During the last decades, the incidence of ischemic enteritis increases, while the mortality rate remains consistently high $(70-90 \%)^{6,7}$. The disease affects patients of different ages and is associated with various conditions such as atherosclerosis, systemic lupus erythematosus, or diabetes mellitus ${ }^{8,9}$.

Acute mesenteric ischemia is followed by a sequence of events that exacerbate the clinical manifestations of the disease and lead to systemic inflammatory response (SIRS) and multiple organ failure (MODS). This sequence of events includes activation of cytokines, reactive oxygen species, neutrophils and platelet activating factor, by processes such as bacterial overgrowth, disruption of intestinal barrier, bacterial translocation, and bacteremia ${ }^{10-12}$. Recently, the inflammatory and immunological processes that are triggered by intestinal ischemia, as well as those nutritional agents that could possibly modify patient's outcome are extensively studied, leading to the concept of immunonutrition. This includes, among others, special diets rich in n-3 polyunsaturated fatty acids (PUFA) which are thought to affect the inflammatory and immunological response. Main sources of $n-3$ fatty acids are oily fish ${ }^{13}$. Recent studies suggest that metabolites of $n-3$ fatty acids reduce inflammatory response in compare to arachidonic acid derivatives that arise from n-6 fatty acids ${ }^{14-17}$.
The present study compares the effects on the inflammatory process of high-molecular solution enriched with n-3 fatty acids, compared to a corresponding artificial high-molecular polymer total enteral nutrition in Wistar rats with controlled narrowing of the superior mesenteric artery leading to ischemic enteritis.

\section{Materials and Methods}

\section{Laboratory animals}

The animal protocol was designed to minimize pain or discomfort to the animals. For the purposes of this study, we used 40 Wistar rats. The rats were all of the same sex, female, to minimize variations, 2-monthold and weighted between 150 and $200 \mathrm{~g}$. The rats originated from a breeding colony established at the Experimental Laboratory of "Theageneio" Hospital of Thessaloniki where they remained until the age of 2 months. Then, they were transferred at the Experimental Laboratory of the Veterinary School of the Aristotle University of Thessaloniki where they stayed for 7-10 days before the onset of the experimental study. The laboratory environment had a constant temperature, humidity, and ventilation, while special timers secured a 12-h light and dark cycle. The animals were kept in cages in pairs under excellent sanitary conditions and had free access to food and water. The experiments followed the existing provisions of the European Convention for the protection of animals used for experimental and research purposes (N.1197/81 Arthr.4, N. 2015/92, PD 160/91). $A$ veterinarian supervised the whole experimental procedure and the research protocol was approved by the Ethical Committee of the Department of Veterinary Services of the Prefecture of Thessaloniki (S.N.: 13/3564/03.26.2010).

\section{Anesthesia}

The surgery was performed under general anesthesia. Initially, a volatile anesthetic was used for a few second, which was achieved by placing the animals in a glass cage which contained gauze impregnated 
with ether. Then, sodium thiopental solution was injected intraperitoneally at a dose of $30 \mathrm{mg} / \mathrm{kg}$ of body weight. This anesthetic regimen ensured analgesia and control of the mobility and irritability of the rat for about $1 \mathrm{~h}$.

\section{Surgical technique}

After the induction of anesthesia, the abdomen of the animal was shaved and sterilized using $10 \%$ Povidone-iodine. Then, it was placed on a sterile operating table, the limbs were immobilized and sterile surgical sheets were placed on the abdominal wall. A midline three-cm abdominal incision was made through which the superior mesenteric artery was recognized. A $23 G$ needle (diameter $0.65 \mathrm{~mm}$ ) was placed on the vessel and tied with 4-0 silk suture ${ }^{18}$. The needle was then removed achieving in this way a controlled narrowing of the superior mesenteric artery of about $65-70 \%{ }^{19}$. Blood samples were collected before the procedure, which were centrifuged and stored at $-80^{\circ} \mathrm{C}$. Finally, the abdominal wall was closed in one layer using a 3-0 silk suture and the surgical incision was carefully cleaned. Net operative time ranged between 15 and $20 \mathrm{~min}$. No antibiotics were administered. After the procedure, the rats were placed in pairs back in the cages and were monitored for about $1 \mathrm{~h}$ until fully recovered.

\section{Experimental setup}

Ischemic enteritis was induced by controlled narrowing of the superior mesenteric artery, and following the rats were divided randomly into two groups: N3PUFA $(n=20)$ - Following surgery rats were solely fed with a high-molecular polymer artificial total enteral nutrition enriched with $n-3$ PUFA in a ratio $n$ $6 / n-3=0.3 / 1.0$, containing eicosapentaenoic acid and docosahexaenoic acid for 15 days (ProSure ${ }^{\circledR}$, Abbott $240 \mathrm{ml}$ ). The detailed ingredients of the diet are shown in table 1. During the autopsy, blood and tissue samples were taken. Control $(n=20)$ - Control Group: Following surgery rats were solely fed with a highmolecular polymer artificial total enteral nutrition (Ensure Plus ${ }^{\circledR}$, Abbott $200 \mathrm{ml}$ ) containing alpha linolenic acid for 15 days. The detailed ingredients of the diet are shown in table 1. During the autopsy, blood and tissue samples were taken.

Pilot studies showed that the daily consumption of the nutrition formula was $20 \mathrm{ml} / 100 \mathrm{~g}$ body weight/day.
Table 1. Nutritional details of the administrated diet regimens

\begin{tabular}{|c|c|c|}
\hline Nutrition & Prosure & Ensure plus \\
\hline $\begin{array}{l}\text { Characteristics } \\
\text { Energy density } \\
\text { Energy distribution } \\
\text { Protein } \\
\text { Carbohydrate } \\
\text { Fat } \\
\text { Fiber }\end{array}$ & $\begin{array}{c}1.3 \mathrm{kcal} / \mathrm{ml} \\
\\
20.9 \% \\
57.7 \% \\
18.1 \% \\
3.26 \%\end{array}$ & $\begin{array}{l}15 \% \\
57 \% \\
28 \%\end{array}$ \\
\hline Renal solute load & $517 \mathrm{mOsm} / \mathrm{L}$ & 430 mOsm/L \\
\hline Osmolarity & 507 mOsm/L & 509 mOsm/L \\
\hline Osmolality & 753 mOsm/kg H2O & 680 mOsm/kg H2O \\
\hline $\begin{array}{l}\text { Energy (per 1 I) } \\
\text { Energy } \\
\text { Protein }\end{array}$ & $\begin{array}{c}5360 / 1270 \mathrm{KJ} / \mathrm{Kcal} \\
66.5 \mathrm{~g}\end{array}$ & $\begin{array}{c}6320 / 1510 \mathrm{KJ} / \mathrm{Kcal} \\
62.5\end{array}$ \\
\hline $\begin{array}{l}\text { Fat } \\
\text { EPA } \\
\text { DHA } \\
\text { ALA }\end{array}$ & $\begin{array}{c}25.6 \mathrm{~g} \\
4.5 \mathrm{~g} \\
2 \mathrm{~g} \\
-\end{array}$ & $\begin{array}{c}49.2 \mathrm{~g} \\
- \\
- \\
2.75 \mathrm{~g}\end{array}$ \\
\hline Saturated Fat & $7.5 \mathrm{~g}$ & $5.5 \mathrm{~g}$ \\
\hline Carbohydrate & $183.3 \mathrm{~g}$ & $202 \mathrm{~g}$ \\
\hline Sugars & $29 \mathrm{~g}$ & $67 \mathrm{~g}$ \\
\hline Dietary Fiber & $20.7 \mathrm{~g}$ & \\
\hline FOS & $11 \mathrm{~g}$ & $12 \mathrm{~g}$ \\
\hline Salt & $3.8 \mathrm{~g}$ & $2.3 \mathrm{~g}$ \\
\hline Taurine & $200 \mathrm{mg}$ & $150 \mathrm{mg}$ \\
\hline Carnitine & $100 \mathrm{mg}$ & $120 \mathrm{mg}$ \\
\hline $\begin{array}{l}\text { Vitamins (per 1 I) } \\
\text { Vitamin A (acetate) } \\
\text { Vitamin A (beta-carotene) } \\
\text { Vitamin D3 } \\
\text { Vitamin E } \\
\text { Vitamin K1 } \\
\text { Vitamin C } \\
\text { Folic Acid } \\
\text { Thiamine (Vitamin B+) } \\
\text { Riboflavin (Vitamin B2) } \\
\text { Vitamin B6 } \\
\text { Vitamin B12 } \\
\text { Niacin } \\
\text { Pantothenic acid } \\
\text { Biotin } \\
\text { Choline }\end{array}$ & $\begin{array}{c}2050 \mathrm{mcg} \text { RE } \\
700 \mathrm{mcg} \mathrm{RE} \\
17 \mathrm{mcg} \\
200 \mathrm{mg} \mathrm{a}-\mathrm{TE} \\
100 \mathrm{mcg} \\
430 \mathrm{mg} \\
1690 \mathrm{mcg} \\
2.5 \mathrm{mg} \\
2.9 \mathrm{mg} \\
3.4 \mathrm{mg} \\
5 \mathrm{mcg} \\
25 \mathrm{mg} \mathrm{NE} \\
11 \mathrm{mg} \\
50 \mathrm{mcg} \\
510 \mathrm{mg}\end{array}$ & $\begin{array}{c}1170 \mathrm{mcg} R E \\
290 \mathrm{mcg} \mathrm{RE} \\
20 \mathrm{mcg} \\
21 \mathrm{mg} \mathrm{a}-\mathrm{TE} \\
120 \mathrm{mcg} \\
120 \mathrm{mg} \\
400 \mathrm{mcg} \\
2 \mathrm{mg} \\
2.7 \mathrm{mg} \\
2.7 \mathrm{mg} \\
5.5 \mathrm{mcg} \\
26 \mathrm{mg} \mathrm{NE} \\
11 \mathrm{mg} \\
60 \mathrm{mcg} \\
550 \mathrm{mg}\end{array}$ \\
\hline $\begin{array}{l}\text { Minerals (per 1 I) } \\
\text { Sodium } \\
\text { Potassium } \\
\text { Chloride } \\
\text { Calcium } \\
\text { Phosphorus } \\
\text { Magnesium } \\
\text { Ferrum } \\
\text { Zinc } \\
\text { Manganese } \\
\text { Copper } \\
\text { lodine } \\
\text { Selenium } \\
\text { Chromium } \\
\text { Molybdenum }\end{array}$ & $\begin{array}{c}1500 \mathrm{mg} \\
2000 \mathrm{mg} \\
1520 \mathrm{mg} \\
1480 \mathrm{mg} \\
1050 \mathrm{mg} \\
420 \mathrm{mg} \\
6.5 \mathrm{mg} \\
250 \mathrm{mg} \\
4.2 \mathrm{mg} \\
780 \mathrm{mcg} \\
160 \mathrm{mcg} \\
79 \mathrm{mcg} \\
100 \mathrm{mcg} \\
140 \mathrm{mcg}\end{array}$ & $\begin{array}{c}920 \mathrm{mg} \\
1600 \mathrm{mg} \\
1100 \mathrm{mg} \\
1200 \mathrm{mg} \\
1000 \mathrm{mg} \\
300 \mathrm{mg} \\
21 \mathrm{mg} \\
160 \mathrm{mg} \\
5 \mathrm{mg} \\
2200 \mathrm{mcg} \\
220 \mathrm{mcg} \\
83 \mathrm{mcg} \\
135 \mathrm{mcg} \\
160 \mathrm{mcg}\end{array}$ \\
\hline
\end{tabular}


Hence, the estimated levels of total n3 fatty acids in the N3PUFA group administrated were $0.13 \mathrm{~g} / 100 \mathrm{~g}$ body weight/day, so each animal received approximately $0.195-0.26 \mathrm{~g}$ of $\mathrm{n} 3$ fatty acids per day and in the CONTROL group was $0.055 \mathrm{~g} / 100 \mathrm{~g}$ body weight/ day, so each animal received approximately 0.0825 $0.11 \mathrm{~g}$ of $\mathrm{n} 3$ fatty acids/day.

\section{Autopsy}

The sacrifice was scheduled on the $15^{\text {th }}$ post-operative day. After anesthetizing the animals with ether in a glass cage, the abdominal wall was reopened and blood samples $(0.7 \mathrm{ml})$ as well as tissue samples from the small intestine were received. The blood samples were centrifuged immediately and stored at $-80^{\circ} \mathrm{C}$ to perform the necessary measurements. The tissue samples included resection of a $1-\mathrm{cm}$ part of the small intestine at around $5 \mathrm{~cm}$ away from the ileocecal valve which was placed in a $4 \%$ formalin solution and sent for histological examination. Finally, the animals were sacrificed by intracardiac administration of $\mathrm{KCl} 10 \%$.

\section{Body weight}

The body weight of every animal was measured at the start of the experiment using a precision scale and, then, again before the sacrifice and the results were recorded based on the code of animal. The average body weight was calculated per group and the changes between the beginning of the experiment and before sacrifice were compared.

\section{Cytokine measurement: interleukin (IL) $1 b$, IL-6, and tumor necrosis factor a (TNF-a)}

The measurement of cytokines IL-1b, IL-6, and TNFa was made in the blood serum. The samples were collected on the $1^{\text {st }}$ day, before the narrowing of the superior mesenteric artery, and on the $15^{\text {th }}$ day, before the sacrifice. The samples were centrifuged immediately and stored at $-80^{\circ} \mathrm{C}$. Measurement of cytokines was performed with commercial available ELISA kits.

\section{Histology}

Small parts of the terminal ileum were sent for histological examination. After dehydration in alcohol, representative sections were embedded in paraffin and then, from these, 5 - $\mu$-thick sections were taken and stained with hematoxylin-eosin. The evaluation of ischemic lesions of the intestinal mucosa was made in accordance with the scale of Chiu et al. ${ }^{20}$, as shown below: $0=$ Normal mucosal villi. $1=$ Growth of a submucosal space of Gruenhagen's (A space created by the separation of the mucosa from the basal membrane as a result of ischemia). The epithelial cells have a normal appearance at the top of the intestinal villi, often with capillary congestion. 2 = Extension of the submucosal space with moderate elevation of the epithelial layer from the basal membrane. $3=$ Marked elevation of the mucosa along the villi and small number of denuded villi. 4 = Denuded villi with exposure of the basal membrane and dilated capillaries. 5 = Digestion, disintegration of the basal membrane, bleeding, and ulceration.

\section{Statistical analysis}

After testing for normality, the Mann-Whitney statistical test was employed for the comparison, between the two groups N3PUFA and CONTROL, of body weight (before the experiment and before autopsy), of body weight loss, of cytokines IL-1b, IL-6, TNF-a, and the extend of ischemic lesions. In all of the non-parametric tests, the level of significance ( $p$-value) was calculated by the method of simulations of Monte-Carlo (10,000 resampling $)^{21}$. With this method safe inferences were achieved, even when the methodological requirements of the statistical tests were not met. The Wilcoxon statistical test was performed to evaluate variations in body weight and blood cytokines between the beginning of the experiment and the sacrifice, for each group. In all statistical tests, the level of significance was predetermined at $p \leq 0.05$. Statistical analysis was performed using the SPSS V.15.0 software (SPSS Inc., IL: Chicago, USA).

\section{Results}

\section{Mortality}

No deaths occurred until the day of sacrifice.

\section{Body weight}

No statistically significant difference was observed in body weight between the two groups at the beginning of the experiment $(p=0.457)$ as well as at the day of sacrifice $(p=0.091)$. However, the body weight 
loss was significantly lower in the N3PUFA group compared to control $(p=0.004)$. According to the Wilcoxon test, there was a statistically significant decrease in body weight in both groups between the beginning of the experiment and the time before the sacrifice $(p<0.001)$. All the changes in body weights of both groups are presented as a bar graph in figure $1 \mathrm{~A}$ and body weight loss in figure $1 \mathrm{~B}$.

\section{Measurement of cytokines (IL - 1b, IL -6, and TNFa)}

The values of cytokines (IL - 1b, IL -6, and TNFa) in both experimental groups at the start of the experiment were compared and no statistically significant difference was found $(p=0.641, p=0.381, p=0.184$, respectively). Furthermore, the statistical test, concerning the cytokines, IL- $1 \mathrm{~b}, \mathrm{IL}-6$, and TNF at the sacrifice, did not reveal a statistically significant difference between the two groups ( $p=0.279, p=0.265$, and $p=0.254$, respectively). According to the Wilcoxon test, there was a statistically significant increase in cytokines levels in both groups between the beginning of the experiment and the time before the sacrifice $(p<0.001)$. The results of these comparison are shown as a bar graph in figures $2 \mathrm{~A}-\mathrm{C}$, respectively.

\section{Histology}

According to Chiu scale, in group N3PUFA, the severity of intestinal ischemia ranged from $1-5$, with a mean of 2.8 , while in group control, the severity of intestinal ischemia ranged from 3-5, with a mean of 4.3. Statistical control revealed that in Group N3PUFA the mean intestinal gravity value was statistically lower than in group control $(p<0.001)$. The difference is illustrated as a bar graph in figure 3 .

\section{Discussion}

Acute mesenteric ischemia is a life-threatening condition with an unfavorable prognosis. The disease is known since $1875^{22}$, however, during the past decades, its frequency is continuously increasing and affects one case for every 1000 admissions ${ }^{23-25}$. The causes of the disease include occlusion of the superior mesenteric artery due to embolus in $50 \%$ of cases, thrombosis of the superior mesenteric artery $(25 \%)$ or vein (5\%) and non-occlusive intestinal ischemia in
$\mathrm{A}_{2}$
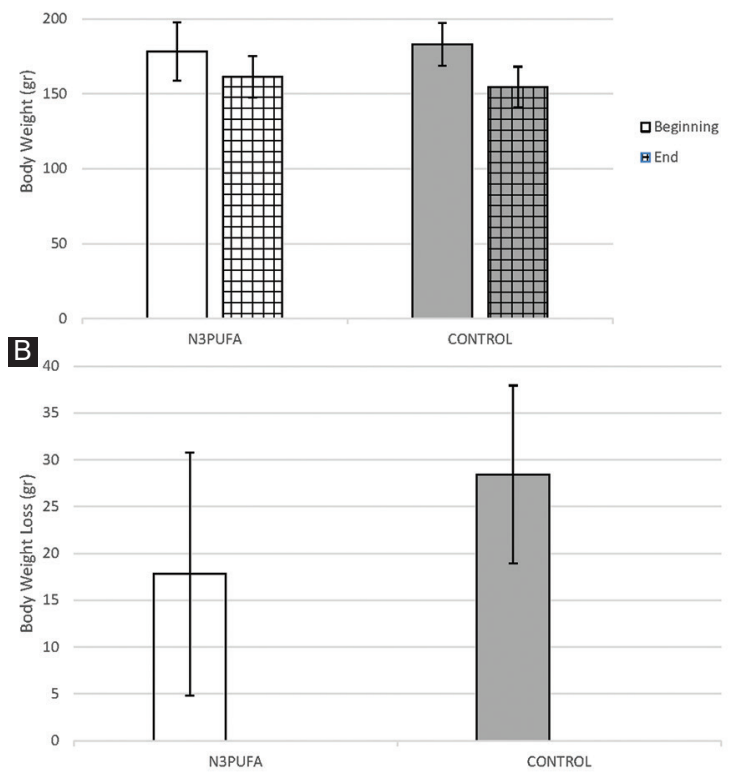

Figure 1. A: comparison of body weight of the two groups at the beginning of the experiment and prior to sacrifice (mean \pm standard deviation). No statistically significant difference was noted between the subgroups neither at the beginning nor at the end of the experiment, but the decrease of body weight within each subgroup was statistically significant $(p<0.001)$. B: comparison of body weight loss of the two groups (mean \pm standard deviation). In the N3PUFA there was statistically significant decreased weight loss compared to CONTROL $(p=0.004)$.

$20 \%{ }^{23}$. Various studies have indicated that the causes of the disease are related directly to mortality, for example mesenteric vein thrombosis is considered to have more favorable outcome when compared with a superior mesenteric artery embolus. Most researchers conclude that the diagnosis of the disease in the first $24 \mathrm{~h}$ of the onset of symptoms and before the installation of irreversible damage to the intestinal wall dramatically improves survival rates ${ }^{4}$. The predisposing factors of the disease include age older than 50 in associations with congestive heart failure, arrhythmias, history of a recent heart attack, hypovolemia, hypotension, and sepsis ${ }^{26}$. Furthermore, high risk is thought to be patients with a history of arterial embolism, vasculitis, and deep venous thrombosis, as well as patients with hypercoagulable states, such as deficiency of protein $\mathrm{C}$ and $\mathrm{S}$ and antithrombin III. However, acute mesenteric ischemia, also, occurs in younger people with none of the above risk factors ${ }^{4}$.

The effects of acute mesenteric ischemia in the intestinal wall are the same regardless of the etiology, ranging from simple disturbances of the 




Figure 2. A: comparison oflL-1b of the two groups at the beginning of the experiment and before sacrifice (mean \pm standard deviation). There was no statistically significant difference, but increase in cytokines levels within each subgroup was statistically significant $(p<0.001)$. B: comparison of IL- 6 of the two groups at the beginning of the experiment and before sacrifice (mean \pm standard deviation). There was no statistically significant difference, but increase in cytokines levels within each subgroup was statistically significant $(p<0.001)$. C: comparison of TNF-a of the two groups at the beginning of the experiment and before sacrifice (mean \pm standard deviation) There was no statistically significant difference but increase in cytokines levels within each subgroup was statistically significant $(p<0.001)$.

intestinal function to wall necrosis and peritonitis ${ }^{27}$. Tissue damage is associated as well with the release of oxygen free radicals during reperfusion. Oxygen free radicals cause cellular damage and damage of the mucosal barrier, promoting in this way bacterial translocation, which is responsible for sepsis and MODS ${ }^{28}$.

During the past decades, various experimental models have been used in order to study the mechanism of ischemic bowel necrosis. The most commonly used experimental animal is the rat and ischemic necrosis is achieved by mechanical obstruction of the superior mesenteric artery. Initially, occlusion of the superior mesenteric artery was achieved by ligation, but this technique was accompanied by a high

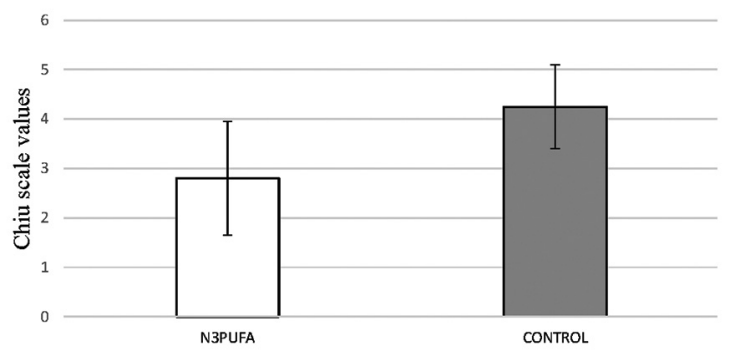

Figure 3. Comparison of the distribution of Chiu-scale values of the two groups (mean). In the N3PUFA there was statistically significant fewer lesions compared to CONTROL $(p<0.001)$.

mortality rate $(8-80 \% \text { in the first } 85 \mathrm{~min})^{29-31}$. Therefore, scientists realized that the study of ischemic bowel necrosis based on these protocols wasn't reproducible or reliable, especially for testing the effect of certain drugs ${ }^{32}$. So they introduced protocols that involved partial occlusion of the superior mesenteric artery $^{33}$.

In this study, we used an experimental model in rats, where we achieved a controlled narrowing of the superior mesenteric artery using a 23 gauge needle (diameter: $0.65 \mathrm{~mm}$ ). The stenosis resulted in ischemic lesions of the small intestine which were classified based on the scale by Chiu et al. ${ }^{20}$. Picazo et al., in a similar experiment, observed that, after controlled narrowing of the superior mesenteric artery, larger lesions were found in the terminal ileum which was gradually evolving through time, from simple mucosal lesions during the first $24 \mathrm{~h}$ to wall necrosis after $72 \mathrm{~h}^{34}$.

Moreover, in the present study, we observed a statistically significant decrease in body weight of the animals before and after the occlusion of the superior mesenteric artery in both groups. However, the comparison between the two groups revealed no statistically significant difference. Kotani et al. reached the same conclusion in their experimental mode ${ }^{19}$. Based on the previous studies of Jones et al. and Stoney and Reilly, the weight loss in ischemic enteritis is due to abdominal pain that accompanies food intake and leads the animals to avoid feeding ${ }^{35,36}$.

The inflammatory reaction of acute mesenteric ischemia is accompanied by alterations in the diameter and permeability of the microvascular circulation. Increased vascular permeability leads to the exit of plasma proteins and leukocytes to the interstitium and migration of lymphocyte to the site of the injury ${ }^{37}$. The major "chemotactic" agent is the bacterial endotoxin (also 
known as lipopolysaccharide) which is a component of the cell membrane of Gram-negative bacteria and leads to activation of monocytes and macrophages and production of cytokines, such as TNF-a, IL-1, IL-6, IL-8, and eicosanoids such as prostaglandin $\mathrm{E} 2^{38}$.

Cytokines that are associated with the inflammatory process are IL-1, TNF-a, and TNF-b and IL- 8 . IL-1 and TNF-a derive from activated macrophages, while TNF-b by activated T lymphocytes. IL-1 and TNF-a are mainly related to effects such as adhesion of leukocytes to the vascular endothelium, production of prostaglandins, reduction of anticoagulant activity, and upregulation of IL-1, IL-6, IL-8, and PDGF ${ }^{39}$.

Cytokines produced by monocytes and macrophages modulate the response to infection and trauma. Their actions are downregulated by anti-inflammatory cytokines such as IL-10. Although the inflammatory response is a normal and necessary process, the uncontrollable activation can cause serious damage to the organism. High concentrations of TNF-a, IL-1, and IL- 6 have been associated with pathological responses that occur in septic shock, acute respiratory failure, rheumatoid arthritis, and inflammatory bowel disease ${ }^{38}$.

Several studies suggest that the quantity and type of fatty acid intake may influence lymphocyte function. In experimental protocols using diets based on fish oils, there was an alteration of the function of lymphocytes and suppression of the production of pro-inflammatory cytokines by macrophages ${ }^{39}$. Similar findings were reported in a protocol, wherein healthy volunteers received a diet rich in n-3 PUFA and there was a reduction in the concentration of monocytes and leukocytes and in the production of pro-inflammatory cytokines ${ }^{40}$.

There are several studies that suggest that the intestine produces large quantities of IL-1, TNF-a, oxygen free radicals and therefore IL- 6 due to ischemia, although the exact pathway is not quite clear. Furthermore, intestinal ischemia leads to a bacterial overload which leads, then, to an increase in IL-6 and TNF- $\mathrm{a}^{41}$. Moore et al. have demonstrated high levels of cytokines in blood samples taken from mesenteric vessels 60-120 min after induction of intestinal ischemia. Therefore, they concluded that high levels of cytokines are early prognostic indicators of acute intestinal isch$\mathrm{emia}^{42}$. Based on these and on similar observations, Karadaac et al. tried to use the measurement of cytokines for the early diagnosis of acute mesenteric ischemia. However, their results did not show statistically significant difference and also the determination of the level of cytokines was time consuming and could not overcome the great challenge of early diagnosis ${ }^{41}$. In the present study, we measured the level of serum cytokines IL-1b, IL-6, and TNF-a prior and after the occlusion of the superior mesenteric artery in both groups and no statistically significant difference were found. Based on these results, we concluded that the administration of an enriched in n-3 PUFA diet failed to achieve reduction of the level cytokines and thus a possible modification of the SIRS. However, the tissue levels of cytokines were not measured and so a local anti-inflammatory response cannot be ruled out.

It is well known that PUFA play an important role in various biological functions. The long chain $n-6$ PUFA, and especially arachidonic acid (20: $4 n-6)$, are precursors of eicosanoids and contribute to the production of prostaglandins and leukotrienes ${ }^{43}$. There are many studies that correlate the consumption of PUFA with the pathogenesis of inflammatory bowel diseases and, in particular, through their involvement in the inflammatory response ${ }^{44,45}$. In recent decades, the influence of western diet on the inflammatory process has been extensively studied. Typical Western diets include a high ratio of $n-6 / n-3$ PUFA. N-6 PUFA are the precursor of arachidonic acid which is a strong pro-inflammatory agent ${ }^{37,46}$. On the contrary, n-3 PUFA, which are found in large quantities in fish oils, are considered to have various beneficial properties, particularly in the regulation of inflammatory and immune response. In general, n-3 fatty acids derivatives are thought to activate milder inflammatory and immune responses compared with the arachidonic acid derivatives. For this reason, researchers believe that they probably promote a milder inflammatory response compared to $n-64$.

As mentioned above, acute mesenteric ischemia inevitably evolves into SIRS and MODS. Sepsis and septic shock are the main causes of death in these patients in intensive care units. The SIRS is triggered by both bacterial translocation and the systemic response to tissue damage ${ }^{48}$. Many researchers try to evaluate the potential beneficial role of $n-3$ PUFA. Therefore, they introduced the concept of "immunonutrition" which includes diets with a specific fatty acid composition that could affect the inflammatory and immune response ${ }^{48}$. In several studies, the use of an enteral diet rich in $\mathrm{n}-3$ fatty acids after a major surgery or injury resulted in reduction of septic complications ${ }^{49}$. Furthermore, administration of enteral or parenteral diet rich in $n-3$ fatty acids in septic models resulted in increased survival and reduced respiratory failure ${ }^{50}$. In this study, we observed a difference 
in ischemic lesions between the two experimental groups. Specifically, there was a statistically significant reduction in the mean intestinal lesions in the group that received an enteral diet rich in n-3 PUFA. Based on these findings, it is thought that a diet rich in $\mathrm{n}-3$ fatty acids may be beneficial and can significantly reduce the impairment of the intestinal mucosa villi, by modifying the local, but not the systemic, immune, and inflammatory response.

\section{Conclusions}

The use of a diet enriched with n-3 PUFA is beneficial by reducing the damage of intestinal mucosa accompanying the acute mesenteric ischemia. N-3 fatty acids healing induction may be caused by modifying the local inflammatory and immune response of the gastrointestinal tract, which was not measured in the current experiment, to intestinal ischemia.

\section{Declaration of interests}

The authors declare no competing financial interests or conflicts of interest.

\section{Ethical disclosures}

Protection of human and animal subjects. The authors declare that the procedures followed were in accordance with the regulations of the relevant clinical research ethics committee and with those of the Code of Ethics of the World Medical Association (Declaration of Helsinki).

Confidentiality of data. The authors declare that no patient data appear in this article.

Right to privacy and informed consent. The authors declare that no patient data appear in this article.

\section{References}

1. Kougias P, Lau D, El Sayed HF, Zhou W, Huynh TT, et al. Determinants of mortality and treatment outcome following surgical interventions for acute mesenteric ischemia. J Vasc Surg. 2007;46:467-74.

2. Herbert GS, Steele SR. Acute and chronic mesenteric ischemia. Surg Clin North Am. 2007;87:1115-34.

3. Kornblith PL, Boley SJ, Whitehouse BS. Anatomy of the splanchnic circulation. Surg Clin North Am. 1992;72:1-30.

4. Brandt LJ, Boley SJ. AGA technical review on intestinal ischemia. Gastroenterology. 2000;118:954-68.

5. Oldenburg WA, Lau LL, Rodenberg TJ, Edmonds HJ, Burger CD. Acute mesenteric ischemia. Arch Intern Med. 2004;164:1054-62.

6. Mamode N, Pickford I, Leiberman P. Failure to improve outcome in acute mesenteric ischaemia: seven-year review. Eur $\mathrm{J}$ Surg. 1999;165:203-8.

7. Jrvinen O, Laurikka J, Salenius JP, Tarkka M. Acute intestinal ischemia. A review of 214 cases. Ann Chir Gyn. 1994;83:22-5.
8. Dimeglio LA, Chaet MS, Quigley CA, Grosfeld JL. Massive ischemic intestinal necrosis at the onset of diabetes mellitus with ketoacidosis in three-year-old girl. J Ped Surg. 2003;38:1537-9.

9. Lazaris AC, Papanikolaou IS, Theodoropoulos GE, Petraki K, Davaris PS. Ischaemic necrosis of the rectum and sigmoid colon complicating systemic lupus erythematosus. Acta Gastr Bel. 2003;66:191-4.

10. Patel A, Kaleya RN, Sammartano RJ. Pathophysiology of mesenteric ischaemia. Surg Clin North Am. 1992;72:31-41.

11. Gennari R, Alexander JW, Eaves-Pyles T. Effect of different combinations of dietary additives on bacterial translocation and survival in gut-derived sepsis. JPEN. 1995;19:319-25.

12. Ioannidis $O$, Lavrentieva $A$, Botsios D. Nutrition support in acute pancreatitis. JOP. 2008;9:375-90.

13. Nicolaou A. Prostanoids. In: Nicolaou A, Kafatos G, editors. Bioactive Lipids. Bridgewater: The Oily Press; 2004. p. 197-222.

14. Wesley JA. Immunonutrition: the role of $\omega-3$ fatty acids. Nutrition. 1998;14:627-33.

15. Fiore S. Leukotrienes and lipoxins. In: Nicolaou A, Kafatos G, editors. Bioactive Lipids. Bridgewater: The Oily Press; 2004. p. 223-43.

16. Ioannidis O, Varnalidis I, Paraskevas G, Botsios D. Nutritional modulation of the inflammatory bowel response. Digestion. 2011;84:89-101.

17. Varnalidis I, loannidis O, Karamanavi E, Ampas Z, Poutahidis T, Taitzoglou I, et al. Omega 3 fatty acids supplementation has an ameliorative effect in experimental ulcerative colitis despite increased colonic neutrophil infiltration. Rev Esp Enferm Dig. 2011;103:511-8.

18. Kotani T, Komatsu Y, Nakamori Y, Takeuchi K. A novel model of ischemic enteritis induced in rats by stenosis of the superior mesenteric artery. Life Sci. 2009;84:615-21.

19. Fisher EM, Khan M, Salisbury R, Kuppusamy P. Noninvasive monitoring of small intestinal oxygen in a rat model of chronic mesenteric ischemia. Cell Biochem Biophys. 2013;67:9611.

20. Chiu CJ, McArdle AH, Brown R, Scott HJ, Gurd FN. Intestinal mucosal lesion in low-flow states. I. A morphological, hemodynamic, and metabolic reappraisal. Arch Surg. 1970;101:478-83.

21. Mehta C, Patel R. SPSS Exact Test 7.0 for Windows. Chicago: SPSS Inc; 1996.

22. Edwards MS, Cherr GS, Craven TE, Olsen AW, Plonk GW, Geary RL, et al. Acute occlusive mesenteric ischemia: surgical management and outcomes. Ann Vasc Surg. 2003;17:72-9.

23. Stoney RJ, Cunningham CG. Acute mesenteric ischemia. Surgery. 1993;114:489-90.

24. Lock G. Acute intestinal ischemia. Best Pract Res Clin Gastroenterol. 2001;15:83-98.

25. McMillan WD, McCarthy WJ, Bresticker MR, Pearce WH, Schneider JR, Golan JF, et al. Mesenteric artery bypass: objective patency determination. J Vasc Surg. 1995;21:729-40.

26. Boley SJ, Sprayregan S, Veith FJ, Siegelman SS. An aggressive roentgenologic and surgical approach to acute mesenteric ischemia. Surg Ann. 1973;5:355-78.

27. Burns BJ, Brandt LJ. Intestinal ischemia. Gastroenterol Clin North Am. 2003;32:1127-43.

28. Berber I, Aydin C, Cevahir N, Yenisey C, Gumrukcu G, Kocbil G, et al. Tempol reduces bacterial translocation after ischemia/reperfusion injury in a rat model of superior mesenteric artery occlusion. Surg Today. 2009;39:407-13.

29. Boorstein JM, Ducey LJ, Cronenwett JL. Pharmacologic treatment of occlusive mesenteric ischemia in rats. J Surg Res. 1988;44:555-60.

30. Dalsing MC, Grosfeld JL, Shiffler MA, Vane DW, Hull M, Baehner RL, et al. Superoxide dismutase: a cellular protective enzyme in bowel ischemia. J Surg Res. 1983;34:589-96.

31. Haglind E, Haglund U, Lundgren O, Romanus M, Scherstén T. Graded intestinal vascular obstruction: I. Description of an experimental shock model in the rat. Circulatory Shock. 1980;7:83-91.

32. Megison SM, Horton JW, Chao H, Walker PB. A new model for intestinal ischemia in the rat. J Surg Res. 1990;49:168-73.

33. Meilahn JE, Morris JB, Ceppa EP, Bulkley GB. Effect of prolonged selective intramesenteric arterial vasodilator therapy on intestinal viability after acute segmental mesenteric vascular occlusion. Ann Surg. 2001;234:107-15.

34. Picazo M, Cuxart M, Sans R, Sardá C, Expósito E. Mesenteric ischemia in hemodialysis patients. Nefrologia. 2008;28:198-202.

35. Jones DE, Barton J, Cobden I. Painless small bowel ischemia presenting with diarrhea and weight loss. Am J Gastr. 1998;93:653-5.

36. Stoney RJ, Reilly LM. Chronic visceral ischemia: an often overlooked cause of abdominal pain. Post Med. 1983;74:111-8.

37. Gil A. Polyunsaturated fatty acids and inflammatory diseases. Biomed Pharmacother. 2002;56:388-96.

38. Calder PC. N-3 polyunsaturated fatty acids, inflammation, and inflammatory diseases. Am J Clin Nutr. 2006;83:1505S-9.

39. James MJ, Gibson RA, Cleland LG. Dietary polyunsaturated fatty acids and inflammatory mediator production. Am J Clin Nutr. 2000;71:343S-8.

40. Calder PC. Polyunsaturated fatty acids, inflammation and immunity. Lipids. 2001;36:1007-24. 
41. Karaağaç H, Zeybek N, Peker Y, Yağcl G, Pengül A, Günhan O, et al. Diagnostic value of plasma cytokine levels in acute mesenteric ischemia: an experimental study. Gulhane Med J. 2007;49:216-21.

42. Moore JN, White NA, Berg JN, Trim CM, Garner HE. Endotoxemia following experimental intestinal strangulation obstruction in ponies. Can $\mathrm{J}$ Comp Med. 1981:45:330-2.

43. Ueda Y, Kawakami Y, Kunii D, Okada H, Azuma M, Le DS, et al. Elevated concentrations of linoleic acid in erythrocyte membrane phospholipids in patients with inflammatory bowel disease. Nutr Res. 2008; 28:239-44.

44. Kinsella JE, Lokesh B, Broughton S, Whelan J. Dietary polyunsaturated fatty acids and eicosanoids: potential effects on the modulation of inflammatory and immune cells: an overview. Nutrition. 1990;6:24-44.

45. Robinson DR. Alleviation of autoimmune disease by dietary lipids containing omega-3 fatty acids. Rheum Dis Clin North Am. 1991;17:213-22.
46. Simopoulos A. The importance of the ratio omega-6/omega-3 essential fatty acids. Biomed Pharmacother. 2002;56: 365-79.

47. Brunborg LA, Madland TM, Lind RA, Arslan G, Berstad A, Frøyland L. Effects of short-term oral administration of dietary marine oils in patients with inflammatory bowel disease and joint pain: a pilot study comparing seal oil and cod liver oil. Clin Nutr. 2008;27:614-22.

48. Anastasilakis CD, Ioannidis O, Gkiomisi Al, Botsios D. Artificial nutrition and intestinal mucosal barrier functionality. Digestion. 2013;88:193-208.

49. Senkal M, Mumme A, Eickhoff U, Geier B, Späth G, Wulfert D, et al. Early postoperative enteral immunonutrition: clinical outcome and cost-comparison analysis in surgical patients. Crit Care Med. 1997;25:1489-96.

50. Grimminger F, Wahn H, Mayer K, Kiss L, Walmrath D, Seeger W. Impact of arachidonic versus eicosapentaenoic acid on exotoxin-induces lung vascular leakage. Am J Respi Crit Care Med. 1997;155:513-9. 